\title{
Status and conservation of the critically endangered Trinidad piping-guan Aburria pipile
}

\author{
Floyd E. Hayes ${ }^{1,4, *}$, Bryan Sanasie ${ }^{2,5}$, Ishmaelangelo Samad ${ }^{3}$ \\ ${ }^{1}$ Department of Life Sciences, University of the West Indies, St. Augustine, Trinidad and Tobago \\ ${ }^{2}$ Department of Biology, University of the Southern Caribbean, Maracas Valley, Trinidad and Tobago \\ ${ }^{3}$ El Tucuche Hiking Lodge and Nature Retreat, Loango Village, Maracas, Trinidad and Tobago \\ ${ }^{4}$ Present address: Department of Biology, Pacific Union College, 1 Angwin Avenue, Angwin, California 94508, USA \\ ${ }^{5}$ Present address: 4867 Greenfield Drive Apt. 1, Berrien Springs, Michigan 49103, USA
}

\begin{abstract}
The Trinidad piping-guan Aburria pipile is endemic to the island of Trinidad, where it is critically endangered. We reviewed previously published historical records of the piping-guan and compiled reports from local residents and visiting birders. The piping-guan formerly occurred throughout much of Trinidad at all elevations, except perhaps along the west coast. Currently it is most abundant in the eastern half of the Northern Range, where considerable forest habitat remains, yet it remains rare and local. A few piping-guans may persist in forested areas of southern Trinidad, where the species was last reported in 2000. It may be extirpated in central Trinidad, where it was last reported in 1983. Hunting is clearly the major threat but appears to have declined in the past decade, at least in the Northern Range, due to recent public education campaigns. Recent sightings in areas where the piping-guan had previously not been reported for a century suggest a growing population in the Northern Range. Although deforestation has also contributed to its decline, the piping-guan tolerates limited human disturbances in small-scale agricultural plantations of rural communities as long as canopy trees are left intact in nearby forest and it is not hunted. From 1999 to 2001, we conducted variable-radius point counts in suitable habitat at or near selected localities in the Northern Range where the piping-guan had been reported within the past 2 decades. We detected pipingguans in only 3 of $284(1.6 \%)$ point counts, resulting in an estimated density of 0.22 birds km${ }^{-2}$.
\end{abstract}

KEY WORDS: Aburria pipile $\cdot$ Conservation $\cdot$ Cracidae $\cdot$ Status $\cdot$ Trinidad

\section{INTRODUCTION}

The Trinidad piping-guan Aburria pipile, known locally as the pawi, is a medium-sized species of the avian family Cracidae that is endemic to the island of Trinidad, off the coast of northeastern South America, where it is critically endangered (James \& Hislop 1988, 1997, Collar et al. 1992, Temple 1998, Hayes 2006). The decline of the Trinidad piping-guan was first noted in the late 19th century, when it was already 'rapidly becoming a rare bird' (Chapman 1894, p. 75). By the mid-1930s it was incorrectly thought to be 'confined to the eastern half of the northern range and the extreme south of the island' (Belcher \& Smooker 1935, p. 280). Subsequently, only a few scattered sightings were reported in the technical literature prior to the early 1980s (Worth 1973, ffrench 1969, 1977, 1986). From 1982 to 1987, extensive surveys and interviews with local hunters were conducted by the Wildlife Section of the Trinidad Forestry Division (James \& Hislop 1988 , 1997), providing the first detailed assessment of the piping-guan's status and revealing that it was more widespread than previously thought, with recent sightings reported from the Central Range. Further surveys of 5 potential study sites in the Northern Range were conducted by a group of students from the University of Glasgow in 1989 and 1991 (Alexander et al. 1990, 1992, Alexander 2002). In this paper we review the his- 
torical status of the species, provide data on surveys conducted in the northern range of Trinidad from 1999 to 2001, and discuss the species' conservation.

\section{MATERIALS AND METHODS}

We reviewed previously published historical records of the piping-guan and compiled reports from local residents and visiting birders. The known localities of piping-guans at different time periods were plotted on a map to compare the past and present distributions of the species.

To quantitatively assess the abundance of the piping-guan in the Northern Range, where it is most often reported, we conducted variable-radius point counts (Reynolds et al. 1980) from 1999 to 2001 in suitable habitat at or near selected localities where the piping-guan had been reported within the

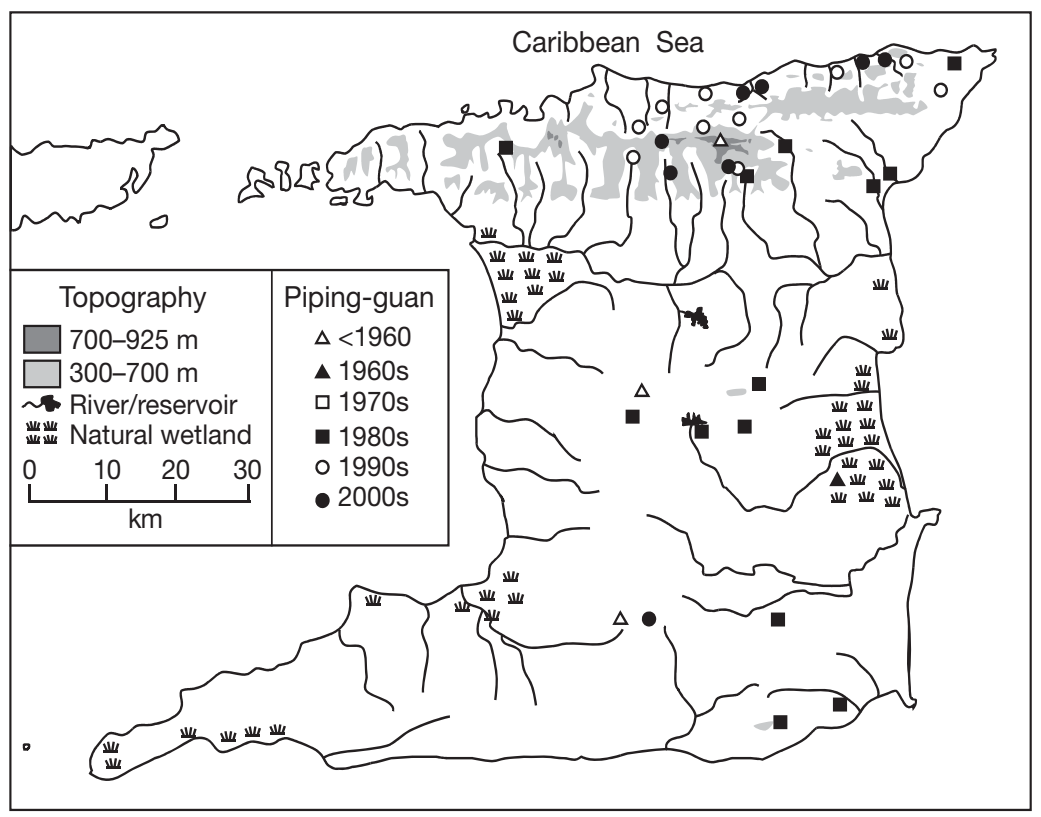

Fig. 1. Historical distribution of the piping-guan Aburria pipile on the island of Trinidad, based on decade of last report for each locality. Note that many of these localities are vague and imprecisely plotted. See Table 1 for further details

past 2 decades. Each count was conducted over a period of 5 min with a distance between successive counts of approximately $250 \mathrm{~m}$ (estimated by counting paces, adjusted for terrain). The distance $(\mathrm{m})$ between the observer and each piping-guan detected (seen or heard) was estimated. Point counts were conducted only during the early morning from 05:45 to 08:00 $\mathrm{h}$, when the pipingguan was most active and easily viewed (F. E. Hayes et al. unpubl. data). Of 284 point counts, 172 were conducted by F. E. Hayes, 60 by B. Sanasie, 36 by I. Samad, 7 by B. D. Hayes, 5 by M. Kenefick, and 4 by F. Lucas. Each observer was previously experienced with identifying piping-guans based on both visual and vocal cues.

\section{RESULTS}

\section{Northern Range}

The piping-guan probably once occurred throughout the Northern Range, although it may have been absent toward the western portion where there are no historical records, possibly because the deciduous seasonal forest habitat typical of the drier western part of the island (Beard 1946) may have been inadequate. The species is distributed mainly in remote areas of the eastern half of the Northern Range (Fig. 1), to the east of the Arima-Blanchiseusse Road.

\section{North slope}

Along the north slope of the Northern Range, the westernmost report is of 3 birds (one shot by a hunter) along Mamoral Trace to the east of the ArimaBlanchiseusse Road near Morne La Croix in 1999 (H. Diaz pers. comm.) (Fig. 1, Table 1). A subsequent survey of Mamoral Trace on 13 April 2001 (Table 2) revealed the habitat to be highly degraded with many small farms. Farther east, where human settlements are sparse and the habitat is less disturbed, pipingguans occurred through the 1990s and early 2000s at several localities off the Paria Waterfall trail: north of Brasso Seco (K. Fitz-James pers. comm.), eastward to La Cuesa (Lapas) Road, and south of Sans Souci (M. Julien pers. comm.), with $\leq 14$ observed at a time in the remote Madamas River forest (R. Lee-Quay pers. comm.) (Fig. 1, Table 1). Habitat destruction is considerable to the east of San Souci, where the pipingguan may be extirpated, although up to 25 ind. were apparently seen in the vicinity of La Par, Toco, near the northeast tip of the island, as late as 1982-1983 (James \& Hislop 1988, 1997) (Fig. 1, Table 1). At readily accessible Grande Riviere, along the north coast, a small population of $\leq 6$ birds has persisted since 1963 at a site $\left(11^{\circ} 49^{\prime} \mathrm{N}, 61^{\circ} 03^{\prime} \mathrm{W}\right)$ along the west side of Monte Video Road, about 0.75 to $1.25 \mathrm{~km}$ south of the Paria Main Road (L. Marin pers. comm.), and others have been seen nearby (Fig. 1, Table 1). 
Table 1. Historical records of the Trinidad piping-guan Aburria pipile through 2002. Note that many of these locations are vague. Geographical sectors are given in parentheses. CT: central Trinidad; NR-ES: Northern Range, east slope; NR-NS: Northern Range, north slope; NR-C: Northern Range, crest; NR-SS: Northern Range, south slope; ST: southern Trinidad

\begin{tabular}{|c|c|c|c|}
\hline Date $(\mathrm{mo} / \mathrm{d} / \mathrm{yr})$ & Location & Details of records & Source \\
\hline \multicolumn{4}{|l|}{ pre-1950 } \\
\hline$?$ & Platanal Valley (NR SS) & Specimen & Vaurie (1967) \\
\hline 04/??/1893 & $11 \mathrm{~km}$ SE of Princes Town (ST) & Specimen & Chapman (1894), Vaurie (1967) \\
\hline 04/19/1902 & Caparo (CT) & Specimen & Hellmayr (1906), Vaurie (1967) \\
\hline 05/20/1934 & Cerro del Aripo (NR-C) & Heard only & Belcher \& Smooker (1935) \\
\hline $1940 \mathrm{~s}$ & Guayaguayare (ST) & Adults and chicks observed & James \& Hislop $(1988,1997)$ \\
\hline $1940 \mathrm{~s}$ & Toco (NR-NS) & Groups of $>12$ observed & James \& Hislop $(1988,1997)$ \\
\hline $1940 \mathrm{~s}$ & Trinity Hills (ST) & Groups of $>12$ observed & James \& Hislop $(1988,1997)$ \\
\hline \multicolumn{4}{|l|}{$1950 \mathrm{~s}$} \\
\hline $1950 \mathrm{~s}$ & Toco (NR-NS) & Observed & James \& Hislop $(1988,1997)$ \\
\hline $1950 \mathrm{~s}$ & Catshill (ST) & Groups of $>15$ observed & James \& Hislop $(1988,1997)$ \\
\hline \multicolumn{4}{|l|}{$1960 \mathrm{~s}$} \\
\hline $1960 \mathrm{~s}$ & Cumaca (NR-SS) & $\leq 5$ observed & James \& Hislop $(1988,1997)$ \\
\hline $1960 \mathrm{~s}$ & Guayaguayare (ST) & $\leq 9$ observed & James \& Hislop $(1988,1997)$ \\
\hline $1960 \mathrm{~s}$ & Aripo (NR-SS) & Groups of 15 to 20 observed & James \& Hislop $(1988,1997)$ \\
\hline $1963 / 1969$ & Grande Riviere (NR-NS) & Few observed & L. Marin (pers. comm.) \\
\hline $3 / 28 / 63$ to $4 / 25 / 63$ & Bush Bush (CT) & 1 observed & Worth (1973) \\
\hline 1966 & Catshill (ST) & Seen twice & James \& Hislop $(1988,1997)$ \\
\hline $04 / 11 / 69$ & Trinity Hills (ST) & 2 observed & ffrench (1969) \\
\hline \multicolumn{4}{|l|}{$1970 \mathrm{~s}$} \\
\hline $1970 \mathrm{~s}$ & Grande Riviere (NR-NS) & Few observed & L. Marin (pers. comm.) \\
\hline $04 / 05 / 75$ & Matura (NR-ES) & 1 observed & ffrench (1977) \\
\hline $08 / ? ? / 75$ to $09 / ? ? / 75$ & Cumaca (NR-SS) & 1 observed with chicks & ffrench (1977) \\
\hline 1979 & La Par, Toco (NR-NS) & 2 observed & James \& Hislop $(1988,1997)$ \\
\hline \multicolumn{4}{|l|}{$1980 \mathrm{~s}$} \\
\hline $1980 \mathrm{~s}$ & Grande Riviere (NR-NS) & Few observed & L. Marin (pers. comm.) \\
\hline 1982 & Near Navet Dam, Central Range (CT) & 1 observed & James \& Hislop $(1988,1997)$ \\
\hline 1982/1983 & La Par, Toco (NR-NS) & 25 observed & James \& Hislop $(1988,1997)$ \\
\hline 1982 & Charuma/Mangold (CT) & 1 observed & James \& Hislop $(1988,1997)$ \\
\hline 12/??/82 & Brasso Pied, Central Range (CT) & 2 observed & James \& Hislop $(1988,1997)$ \\
\hline $12 / ? ? / 82$ to early 83 & Guayaguayare (ST) & 4 observed & James \& Hislop $(1988,1997)$ \\
\hline $12 / ? ? / 82$ to 1986 & Catshill, Moruga (ST) & 5 observed & James \& Hislop $(1988,1997)$ \\
\hline $01 / ? ? / 83$ & El Quemado Road, Tamana (CT) & 2 observed & James \& Hislop $(1988,1997)$ \\
\hline $\begin{array}{l}03 / 18 / 83 \text { to } 03 / 13 / 85 \\
03 / 12 / 85\end{array}$ & Fig Warf, Matura (NR-ES) & 12 observed; 2 chicks observed & James \& Hislop $(1988,1997)$ \\
\hline $03 / ? ? / 83$ to $05 / 02 / 84$ & Madamas (NR-NS) & 2 observed & James \& Hislop $(1988,1997)$ \\
\hline $07 / 18 / 82$ to $07 / 03 / 89$ & Cumaca/Platanal Valley (NR-SS) & $\begin{array}{l}6 \text { observed; } 2 \text { chicks observed } \\
03 / ? ? / 85 ; \text { eggs in cavity 01/??/88 }\end{array}$ & $\begin{array}{l}\text { James \& Hislop }(1988,1997) \\
\text { Alexander et al. }(1990) \\
\text { Alexander (2002) }\end{array}$ \\
\hline 1985 to $08 / ? ? / 89$ & Grande Riviere (NR-NS) & $\leq 3$ observed & $\begin{array}{l}\text { James \& Hislop }(1988,1997) \\
\text { Alexander et al. }(1990), \\
\text { Alexander (2002) }\end{array}$ \\
\hline 1985 to $03 / 27 / 86$ & Aripo (NR-SS) & $\leq 15$ observed & James \& Hislop $(1988,1997)$ \\
\hline 03/??/85 to $04 / ? ? / 86$ & Cumana (NR-ES) & $\leq 3$ observed & James \& Hislop $(1988,1997)$ \\
\hline $10 / 30 / 85$ to $03 / 07 / 86$ & Trinity Hills (ST) & $\leq 3$ observed & $\begin{array}{l}\text { ffrench 1986, James \& Hislop } \\
\quad(1988,1997)\end{array}$ \\
\hline 05/02/86 & Hollis Reservoir (NR-SS) & 5 observed & James \& Hislop $(1988,1997)$ \\
\hline 12/??/86 & Flaghill Road (not located) & 4 observed & James \& Hislop $(1988,1997)$ \\
\hline $1986-1987$ & Kapiot, Santa Cruz (NR-SS) & Observed flying and roosting & James \& Hislop $(1988,1997)$ \\
\hline 04/??/88 & Madamas Rd., E of Brasso Seco (NR-SS) & 1 observed & C. Rooks (pers. comm.) \\
\hline \multicolumn{4}{|l|}{$1990 \mathrm{~s}$} \\
\hline $1990 \mathrm{~s}$ & $\begin{array}{l}\text { Paria Waterfall Trail, Brasso Seco } \\
\text { (NR-NS) }\end{array}$ & Few observed & K. Fitz-James (pers. comm.) \\
\hline $1990 \mathrm{~s}$ & Madamas River forest (NR-NS) & $\leq 14$ observed & R. Lee-Quay (pers. comm.) \\
\hline $1990 \mathrm{~s}$ & Tacarib Bay (NR-NS) & Few observed & C. Adonis (pers. comm.) \\
\hline $1990 \mathrm{~s}$ & Matelot (NR-NS) & $<5$ observed & G. Camacho (pers. comm.) \\
\hline $1990 \mathrm{~s}$ & Naranjo Rd., Cumana (NR-ES) & $\leq 2$ observed & W. Pyke (pers. comm.) \\
\hline $1990 \mathrm{~s}$ & Heights of Aripo (NR-SS) & $\leq 3$ observed & C. Valentine (pers. comm.) \\
\hline
\end{tabular}


Table 1. continued

\begin{tabular}{|c|c|c|c|}
\hline Date $(\mathrm{mo} / \mathrm{d} / \mathrm{yr})$ & Location & Details of records & Source \\
\hline $1990 \mathrm{~s}$ & W of Hollis Reservoir (NR-SS) & $\leq 7$ observed & C. Valentine (pers. comm.) \\
\hline $07 / ? ? / 91$ to $12 / 05 / 99$ & Grande Riviere (NR-NS) & $\leq 3$ observed & $\begin{array}{l}\text { Alexander et al. (1992), } \\
\text { Alexander (2002), Hayes \& } \\
\text { White (2000), authors' (pers. obs.) }\end{array}$ \\
\hline 1996 & La Pastora, Lopinot Valley (NR-SS) & 2 seen regularly until shot & C. Rooks (pers. comm.) \\
\hline 1997 & Ridge above Paria Springs (NR-C) & Few observed & K. Fitz-James (pers. comm.) \\
\hline $02 / ? ? / 97$ to $03 / ? ? ? / 97$ & Madamas Road (NR-NS) & Observed twice & C. Rooks (pers. comm.) \\
\hline 1999 & $\begin{array}{l}\text { La Cuesa (Lapas) Rd., Sans Souci } \\
\text { (NR-NS) }\end{array}$ & 2 observed twice & M. Julien (pers. comm.) \\
\hline 1999 & $\begin{array}{l}\text { Mamoral Trace, Morne La Croix } \\
\text { (NR-NS) }\end{array}$ & 3 observed, 1 shot & H. Diaz (pers. comm.) \\
\hline $10 / 05 / 99$ & Heights of Aripo (NR-SS) & 1 observed & I. Samad (pers. obs.) \\
\hline $11 / 06 / 99$ & $\begin{array}{l}\text { Mile 6.25, Blanchiseusse Rd., } \\
\text { Arima Valley (NR-SS) }\end{array}$ & 1 observed & I. Lambie (pers. comm.) \\
\hline \multicolumn{4}{|l|}{$2000 \mathrm{~s}$} \\
\hline $02 / 24 / 00$ & $\begin{array}{l}\text { Paria Main Rd. east of Shark River } \\
\text { (NR-NS) }\end{array}$ & 2 observed & I. Lucas (pers. comm.) \\
\hline 03/05/00 to $08 / 17 / 02$ & Grande Riviere (NR-NS) & 6 observed & F. Hayes et al. (pers. obs.) \\
\hline 03/??/00 & Naranjo Rd., Cumana (NR-ES) & 2 observed & I. Nero (pers. comm.) \\
\hline $04 / 21 / 00$ & Heights of Aripo (NR-SS) & 1 observed & F. Hayes (pers. obs.) \\
\hline 06/06/00 & $\begin{array}{l}\text { Saunder's Road, Catshill Reserve } \\
\text { (ST) }\end{array}$ & 1 observed & M. Berres (pers. comm.) \\
\hline Spring 2001 & $\begin{array}{l}\text { Mile 10, Blanchiseusse Rd., Arima } \\
\text { Valley (NR-SS) }\end{array}$ & 1 observed & H. Golet \& M. Ramlal (pers. comm.) \\
\hline $02 / 22 / 01$ to $04 / 15 / 01$ & $\begin{array}{l}\text { Communication station, Morne Bleu } \\
\text { (NR-C) }\end{array}$ & 1 observed & R. Neckles et al. (pers. comm.) \\
\hline $02 / 26 / 01$ & $\begin{array}{l}\text { Trail to Lakatan Falls, Grande } \\
\text { Riviere (NR-NS) }\end{array}$ & $\begin{array}{l}\text { Feathers of dead bird, } \\
\text { attributed to natural predation }\end{array}$ & Local resident (pers. comm.) \\
\hline 02/28/01 & $\begin{array}{l}\text { Warden Trace, E of Madamas River } \\
\text { (NR-NS) }\end{array}$ & 1 observed & F. Hayes (pers. obs.) \\
\hline 04/10/01 & $1.2 \mathrm{~km}$ SE of Tacarib Bay (NR-NS) & 2 observed & R. Lee-Quay (pers. comm.) \\
\hline 04/15/01 & $\begin{array}{l}1.5 \mathrm{~km} \mathrm{~S} \text { of Madamas River mouth } \\
\text { (NR-NS) }\end{array}$ & 1 observed & F. Lucas (pers. comm.) \\
\hline
\end{tabular}

South slope

Along the south slope of the Northern Range, there are only 2 published records of the species west of the Arima-Blanchiseusse Road, where the human population is high and habitat destruction and hunting pressure are severe. The westernmost record is from Kapiot, Santa Cruz, based on a vague report of 'unspecified numbers seen flying and roosting' in 1986 and 1987 (James \& Hislop 1988) (Fig. 1, Table 1). Because this is farther west than any other locality where the species has been reported in recent decades (Fig. 1) and in an area where hunting pressure is considerable, we question the record's validity. More recently, a pair of piping-guans was seen regularly for a year until they were shot in 1996 near La Pastora, in upper Lopinot Valley just west of Arima Valley (C. Rooks pers. comm.) (Fig. 1, Table 1). Although hunters in the vicinity of Maracas Valley and El Tucuche (second highest peak) have told us that they never see the piping-guan (presumably extirpated by hunters), there is considerable forest along the northern slope between Santa Cruz and the Blanchiseusse Road, and a few piping-guans may persist in the area. The pair at La Pastora may have derived from a small population on the northern slope and crossed the ridge from the north.

The piping-guan was not included among a comprehensive list of birds observed in Arima Valley during the early 1950s (Beebe 1952). Despite the preservation of suitable forest habitat at Simla, the New York Zoological Society's former tropical research station in the lower valley, and the Asa Wright Nature Centre (AWNC) in the upper valley, the piping-guan was never recorded in Arima Valley - which had been intensively visited by birders daily for several decades - until recently. One was seen by visiting birders at milepost 6.25 of the Blanchiseusse Road on 6 November 1999 (I. Lambie pers. comm.), one was seen at milepost 10 of the Blanchiseusse Road in the spring of 2000 (H. Golet and M. Ramlal reported in AWNC wildlife log), and a single displaying bird was 
periodically seen at the Morne Bleu communication station above the valley along the ridge west of Morne Bleu (third highest peak) from 22 February to 15 April 2002 (R. Neckles et al. pers. comm.) (Fig. 1, Table 1).

To the east of Arima Valley, $\leq 7$ piping-guans were recorded through the 1990s between Heights of Aripo and Hollis Reservoir (C. Valentine pers. comm.), and $\leq 3$ through the 1980s in Cumaca/Platinal Valley (James \& Hislop 1988, 1997, Alexander et al. 1990, Alexander 2002) (Fig. 1, Table 1).

\section{East slope}

There are few records from the east slope of the Northern Range. Up to 2 piping-guans were seen as recently as March 2000 near the Naranjo Road west of Cumana (also known as Redhead; I. Nero pers. comm.) and 12 (including 2 chicks) were seen as recently as 13 March 1985 near Matura (James \& Hislop 1988, 1997) (Fig. 1, Table 1).

Point count surveys

During our 1999 to 2001 surveys in selected areas of the Northern Range, we detected piping-guans in only 3 of 284 (1.6\%) point counts (Table 2, Fig. 2). Of 7 point counts within the home range of a well-studied group at Grande Riviere, a single piping-guan was detected during 2 of these counts (Table 2). A third piping-guan was detected during a count along Warden Trace just east of the Madamas River (Table 2), and a fourth was detected between 2 counts at Heights of Aripo (Table 2). These data are extremely limited for any statistical analyses. Two piping-guans were observed at a distance of about $100 \mathrm{~m}$ and the third at a distance of about $300 \mathrm{~m}$. Based on a band width of $100 \mathrm{~m}$ and ignoring the single detection beyond that range, we calculated the density of piping-guans as 0.22 birds $\mathrm{km}^{-2}$ in suitable habitat of the Northern Range of Trinidad.

\section{Central Trinidad}

The piping-guan is thought to have once occurred throughout the hilly Central Range, even in adjacent lowland areas near sea level close to the east coast; however, there are no published records from hilly terrain near the west coast. The westernmost records are from Caparo, where a specimen was obtained in 1902 (Hellmayr 1906, Vaurie 1967), and in the vicinity of Charuma/Mangold, where one was observed in 1982 (James \& Hislop 1988, 1997) (Fig. 1, Table 1). The east- ernmost record is from near sea level at Bush Bush Island, Nariva Swamp, near the east coast, where one was observed twice in 1963 (Worth 1973) (Fig. 1, Table 1). A few were reported from the Central Range near Tamana and Brasso Pied and in the vicinity of Navet Dam as recently as 1983 (James \& Hislop 1988, 1997) (Fig. 1, Table 1). There are no reports from Arena Forest or Arena Reservoir, north of the Central Range, which are frequently visited by birders.

\section{Southern Trinidad}

Although the piping-guan is thought to have occurred throughout the Trinity Hills and adjacent hilly lowlands of southern Trinidad, there are no reports from the west coast or the Icacos Peninsula of southwestern Trinidad. The westernmost record is from $11 \mathrm{~km}$ SE of Princes Town, where a specimen was obtained in 1893 (Chapman 1894, Vaurie 1967) (Fig. 1, Table 1). The last report from Trinity Hills was on 7 March 1986 (James \& Hislop 1988, 1997) (Fig. 1, Table 1). There are widely scattered records from vague localities in southern Trinidad (Fig. 1, Table 1), and the most recent record is of 2 seen at $06: 45 \mathrm{~h}$ on 6 June 2000 along Access Road CO-40 just off Saunders Road in Catshill Reserve, south of seismic line 613, at $10^{\circ} 12^{\prime} 44^{\prime} \mathrm{N}, 61^{\circ} 14^{\prime} 59^{\prime} \mathrm{W}$ (M. Berres pers. comm.).

\section{DISCUSSION}

The Trinidad piping-guan formerly occurred throughout much of Trinidad, except perhaps along the west coast where there are no records even from hilly areas. The species ranged in elevation from near sea level to the crests of the highest peaks, potentially occurring at the highest elevation on the island (925 m). It currently appears to be most abundant in the eastern half of the Northern Range, where considerable forest habitat remains. A few may still persist in forested areas of southern Trinidad, where it has been reported as recently as 2000. It is uncertain whether any still exist in central Trinidad, where it has not been reported since 1983. Unfortunately, no systematic searches have been conducted in either central or southern Trinidad, where the remaining forests are more accessible to human encroachment. It is likely to become extirpated, if this is not already the case, from central and southern Trinidad.

Piping-guans provide an important source of protein for rural hunters and Amerindians in South America (Brooks 1998), and the Trinidad piping-guan is no exception. More than a century ago Chapman (1894, p. 75) reported that the flesh of this species is 
Table 2. Summary of 5 min point counts for the Trinidad piping-guan Aburria pipile in suitable habitat of the Northern Range of Trinidad, including distance covered, number of point counts, and total number of piping-guans detected

\begin{tabular}{|c|c|c|c|c|c|}
\hline Location & $\begin{array}{l}\text { Date } \\
(\mathrm{mo} / \mathrm{d} / \mathrm{yr})\end{array}$ & Description of area surveyed & $\begin{array}{l}\text { Distance } \\
(\mathrm{km})\end{array}$ & Counts & $\begin{array}{c}\text { Birds } \\
\text { detected }\end{array}$ \\
\hline \multicolumn{6}{|l|}{ North slope } \\
\hline 1. Morne La Croix & $04 / 13 / 01$ & Mamoral Trace, from $1 \mathrm{~km}$ E of Arima-Blanchisseuse Road eastward & 3.5 & 15 & 0 \\
\hline 2. Brasso Seco & 02/04/01 & $\begin{array}{l}\text { Paria Waterfall Trail }{ }^{\mathrm{a}} \text {, from } 0.7 \mathrm{~km} \mathrm{~S} \text { of end of paved road at edge of } \\
\text { forest toward the waterfall }\end{array}$ & 3.5 & 15 & 0 \\
\hline 3. Brasso Seco & $05 / 20 / 01$ & Trail from pass on crest downhill toward Brasso Seco & 2.75 & 15 & 0 \\
\hline 4. Madamas Road & 03/30/01 & $\begin{array}{l}\text { From } 6.6 \mathrm{~km} \mathrm{E} \text { of Brasso Seco Junction eastward to tributaries of } \\
\text { Madamas River }\end{array}$ & 2.5 & 11 & 0 \\
\hline 5. Murphy Bay & 03/31/01 & Forest south of bay & 0.25 & 2 & 0 \\
\hline 6. Petite Tacarib & 04/01/01 & Forest south of bay & 0.25 & 2 & 0 \\
\hline 7. Madamas River & $02 / 28 / 01$ & Paria Main Road, from 0.25 km E of Madamas River eastward ${ }^{a, b}$ & 2 & 9 & 0 \\
\hline 8. Madamas River & $02 / 28 / 01$ & Warden Trace, from 0.1 km S of Paria Main Road southward & 1.75 & 8 & 1 \\
\hline 9. Matelot & 09/05/99 & Paria Main Road, from 0.75 km W of Matelot westward ${ }^{\mathrm{a}, \mathrm{b}}$ & 2.5 & 11 & 0 \\
\hline 10. Matelot & 09/03/99 & Santa Cruz Road, from $1.0 \mathrm{~km} \mathrm{~S}$ of Paria Main Road southward & 2.5 & 11 & 0 \\
\hline 11. Shark River & $05 / 28 / 00$ & Paria Main Road, from Shark River eastward & 2.25 & 10 & 0 \\
\hline 12. Grande Riviere & 03/05/00 & Grande Riviere Road, from $0.5 \mathrm{~km} \mathrm{~S}$ of Paria Main Road southward & 2.75 & 12 & 0 \\
\hline 13. Grande Riviere & $04 / 09 / 00$ & $\begin{array}{l}\text { Esperanza Trace, from } 0.1 \mathrm{~km} \mathrm{~W} \text { of Monte Video Road southward up } \\
\text { to ridge }\end{array}$ & 3 & 13 & 0 \\
\hline 14. Grande Riviere & $\begin{array}{l}03 / 05 / 00 \\
04 / 09 / 00\end{array}$ & $\begin{array}{l}\text { Monte Video Road, from } 0.5 \mathrm{~km} \mathrm{~S} \text { of Paria Main Road to Grande } \\
\text { Riviere study site and side trails }\end{array}$ & 2 & 9 & 2 \\
\hline 15. Montevideo & 05/14/99 & Monte Video Road, from W of Montevideo to Grande Riviere River & 1 & 5 & 0 \\
\hline 16. Sans Souci & $04 / 24 / 00$ & $\begin{array}{l}\text { Trails at end of La Cuesa (Lapas) Road, from } 2.0 \mathrm{~km} \mathrm{~S} \mathrm{of} \mathrm{Paria} \mathrm{Main} \\
\text { Road }\end{array}$ & 3 & 13 & 0 \\
\hline \multicolumn{6}{|l|}{ Crest } \\
\hline 17. Las Lapas & 09/09/01 & Las Lapas Trace west from Blanchisseuse Road ${ }^{\mathrm{a}}$ & 2.25 & 10 & 0 \\
\hline 18. Morne Bleu-West & 03/16/01 & Trail $^{\mathrm{b}}$ from TSTT communications station to summit of Morne Bleu & 2 & 9 & 0 \\
\hline 19. Morne Bleu-East & $05 / 30 / 01$ & Trail $^{\mathrm{b}}$ from $250 \mathrm{~m}$ above pass on crest west toward Morne Bleu & 1 & 5 & 0 \\
\hline 20. El Cerro del Aripo & $04 / 29 / 01$ & Trail $^{\mathrm{b}}$ from trailhead toward Cerro del Aripo & 3.5 & 15 & 0 \\
\hline \multicolumn{6}{|l|}{ South slope } \\
\hline $\begin{array}{l}\text { 21. Lalaja to Guanapo } \\
\text { Valley }\end{array}$ & 06/17/01 & Trail $^{\text {a }}$ to Guanapo Valley beginning at La Laja Road & 3.25 & 14 & 0 \\
\hline 22. Heights of Aripo & $06 / 25 / 00$ & $\begin{array}{l}\text { Unpaved road from Heights of Aripo trailhead to junction of road in } \\
\text { Guanapo Valley }\end{array}$ & 2.5 & 11 & 0 \\
\hline 23. Heights of Aripo & $05 / 19 / 00$ & $\begin{array}{l}\text { Trail a to Chaguaramal from } 0.1 \mathrm{~km} \text { uphill from junction of Aripo } \\
\text { Caves trail to summit and along a side trail }\end{array}$ & 3.25 & 14 & 0 \\
\hline 24. Heights of Aripo & $04 / 21 / 00$ & Trail $^{\mathrm{a}}$ to Aripo Caves from $0.1 \mathrm{~km} \mathrm{~N}$ of trailhead & 2.5 & 11 & $0^{\mathrm{c}}$ \\
\hline 25. Heights of Aripo & 07/09/00 & Trail east of Heights of Aripo toward Hollis Reservoir & 2.5 & 11 & 0 \\
\hline \multicolumn{6}{|l|}{ East slope } \\
\hline 26. Fig Walk/Salybia & $05 / 13 / 01$ & Trail $^{\mathrm{b}} \mathrm{W}$ of Rio Seco beginning just below Salybia Waterfall & 1.75 & 8 & 0 \\
\hline 27. Salybia & $11 / 05 / 00$ & Trail $^{\text {a }}$ to Salybia Waterfall from edge of forest westward to waterfall & 1.5 & 7 & 0 \\
\hline $\begin{array}{l}\text { 28. Cumana/Ravin } \\
\text { Anglais }\end{array}$ & $04 / 23 / 00$ & $\begin{array}{l}\text { Naranjo Road from } 5.9 \mathrm{~km} \text { W of junction with Ravin Anglais Road } \\
\text { westward along road and several trails }\end{array}$ & 2.75 & 12 & 0 \\
\hline
\end{tabular}

deservedly esteemed, and through the persecution of hunters it is rapidly becoming a rare bird.' Hunting, both for subsistence and sport, has clearly been the major threat to the survival of the Trinidad pipingguan, but it has declined in frequency in recent decades - at least in the Northern Range - thanks to public education campaigns orchestrated by the Forestry Division in the early 1980s (James \& Hislop 1997) and by the Rare Center for Tropical Conservation (in conjunction with the Forestry Division) since the late 1990s (Butler 1998). Recent observations of piping-guans in areas where it had not been reported within the past century, especially in the vicinity of Arima Valley and along the west ridge of Morne Bleu, suggest that the population may now be growing and expanding its range. During our surveys we were frequently told by local residents that they ceased hunting the bird after being requested to do so by the Forestry Division, but that outsiders from elsewhere in Trinidad still occasionally hunt the bird. A local resident reported that during Carnival in early March 2000 , the feathers of a piping-guan were found beside 


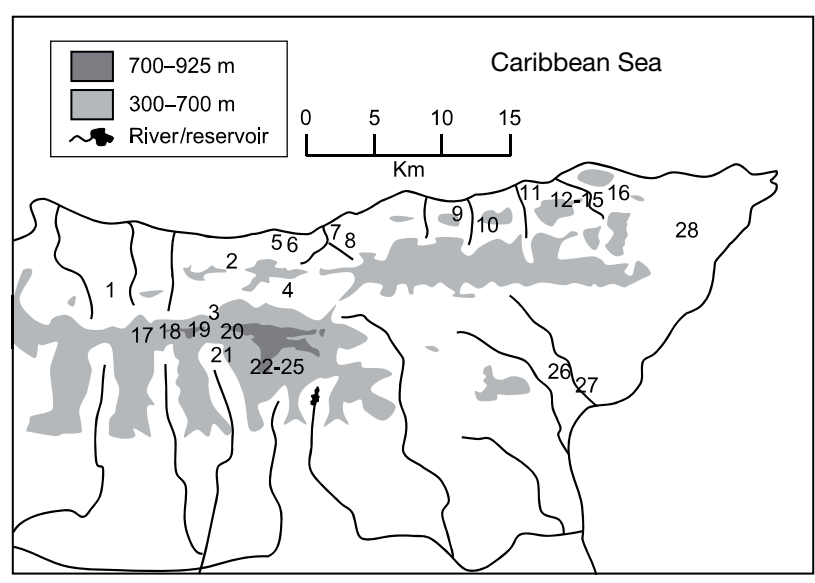

Fig. 2. Locations of surveys conducted for the Trinidad pipingguan Aburria pipile in the Northern Range of Trinidad from 1999 to 2001. Piping-guans were recorded during point counts at Sites 8 and 14, and between point counts at Site 24 .

See Table 2 for numbered locations and further details

a shotgun shell in the hills above Grande Riviere. Hunting may be more prevalent in central and southern Trinidad. Many shotgun shells were found on the ground in the vicinity of the 2 piping-guans found in Catshill Reserve in 2000 (M. Berres pers. comm.).

Deforestation undoubtedly has played a role in the decline of the piping-guan. Because piping-guans forage primarily in the canopy of tall forest trees (Hayes et al. 1999, 2009), forests are required for their survival. The construction of access roads in remote areas is usually accompanied by illegal timber extraction and squatting. Deforestation, most of it conducted illegally, has increased in recent decades as settlers move into the more remote and rugged areas of the eastern part of the Northern Range. Deforestation initially involves the harvesting of timber followed by cultivation of small-scale agricultural crops (including marijuana) or exotic agroforestry plantations (e.g. pine or teak) and the construction of human dwellings. Habitat destruction will almost certainly accelerate if a proposed highway is built to connect an $18 \mathrm{~km}$ stretch of rugged, relatively pristine habitat along the north coast between Blanchisseuse and Matelot (Hayes 2006).

Despite the threat of deforestation, piping-guans are surprisingly tolerant of human activities. For example, a small group of piping-guans has persisted since 1963 at a highly disturbed site along the Monte Video Road at Grande Riviere (L. Marin pers. comm.) and has been the subject of 2 recent studies (Alexander et al. 1990, 1992, Alexander 2002, Hayes et al. 1999, 2009). From 1997 to 2001, a group of $\leq 6$ piping-guans occupied a home range of about 19 ha at this site (Hayes et al. 1999, 2009). The Marins, an elderly couple, lived in a small house near the center of this home range. The house was surrounded by mostly secondary growth forest comprised of native broad-leaved tree species and planted fruit trees including avocado (Persea americana; Lauraceae), banana and plantain (Musa spp.; Musaceae), citrus (Citrus spp.; Rutaceae), mango (Mangifera indica; Anacardiaceae), ornamental nutmeg (Myristica fragrans; Myristicaceae), papaya (Carica papaya; Caricaceae), pomme cythere (Spondias dulcis; Anacardiacae), and pomerac (Spyzgium malaccense; Myrtaceae). Within $1 \mathrm{~km}$ of the house there were several clearings with vegetable gardens attended by local residents who hiked daily along the road from their homes in Grande Riviere. In early 2000, trees were cleared for gardens from an area of 3 to 4 ha and in another area of 1 ha within the home range of the piping-guans, yet the birds remained within the area and were readily observable despite frequent human disturbance. These observations indicate that the piping-guan tolerates limited human disturbances in small-scale agricultural plantations of rural communities as long as canopy trees are left intact in nearby forest and provided it is protected from hunting.

The size of the Trinidad piping-guan population is unknown. Based on 284 point counts with a band width of $100 \mathrm{~m}$, we calculated the density of the piping-guan as 0.22 birds $\mathrm{km}^{-2}$ in suitable habitat of the Northern Range of Trinidad. However, this assumes that all birds within $100 \mathrm{~m}$ were detected, which was unlikely given that we recorded only 2 of the 6 piping-guans known to occur at a well-studied site in Grande Riviere where we conducted 7 point counts, suggesting that our density estimate may be too conservative. BirdLife International (2000) estimated that only $150 \mathrm{~km}^{-2}$ of suitable habitat remained in the Northern Range, but the area encompassed by all sightings in the Northern Range from 1990 to 2001 is approximately $350 \mathrm{~km}^{-2}$. We estimate that the number of piping-guans may range from 77 (based on our conservative estimate of 0.22 birds $\mathrm{km}^{-2}$ ) to 231 (based on a more liberal estimate of 0.66 bird $\mathrm{km}^{-2}$ ). The total population may be $<100$ and is unlikely to exceed 200 .

Despite several recent and ongoing public education campaigns and research projects, a national action plan has yet to be adopted for the conservation of the piping-guan. Nevertheless, several recommendations for conservation actions have already been proposed, including additional research studies, public education campaigns, habitat conservation, stronger law enforcement, and captive breeding (e.g. Collar et al. 1992, James \& Hislop 1988, 1997, Brooks \& Strahl 1998, 2000, Hayes 2006). Our data (Hayes et al. 2009, present study) indicate that the Trinidad piping-guan can thrive when hunting pressure is reduced and canopy trees are left intact in small-scale agricultural plantations, which are the 2 key actions required for conservation. 
Acknowledgements. Funding for this study was generously provided by the St. Louis Zoo. We thank D. Brooks, A. Hailey and 3 anonymous reviewers for reviewing the manuscript. For accompanying us in the field we thank A. Akong, J. Anderson, C. Bartlett, M. Berres, P. Charles, B. Hayes, M. Hayes, M. Kenefick, F. Lucas, J. Lucas, H. Nelson, C. Ramjohn, B. Taylor, G. White, and K. Woods. We also thank D. Brooks, M. Macek, the Marin family, W. Murphy, H. Nelson, J. O'Neill, C. Rooks, $\mathrm{S}$. Temple, and many others who frequently provided us with advice and encouragement. Inexpensive lodging was graciously offered by P. Guerini and the Lucas family.

\section{LITERATURE CITED}

Alexander GD (2002) Observations of the endangered Trinidad piping-guan (Pipile pipile), or pawi, in northern Trinidad. In: Hayes FE, Temple SA (eds) Studies in Trinidad and Tobago ornithology honouring Richard ffrench. Dept Life Sci, Univ West Indies, St. Augustine, Occ Pap 11, p 119-130

Alexander GD, Brown L, Gilbert G (1990) Distribution and habits of the Trinidad piping guan. In: Downie R (ed) Report of the Glasgow University Exploration Society Expedition to Trinidad and Tobago, 1989. University of Glasgow, p 39-59

Alexander GD, Cunningham E, McCaul C, McCormack M (1992) Conservation-related observations of the Trinidad piping guan (Aburria pipile pipile). In: Downie $\mathrm{R}$, Reilly $\mathrm{M}$ (eds) Report of the University of Glasgow Conservation Expedition to Trinidad and Tobago, 1991. University of Glasgow, p 6.1-6.9

Beard JS (1946) The natural vegetation of Trinidad. Clarendon Press, Oxford

Beebe W (1952) Introduction to the ecology of the Arima Valley, Trinidad. Zoologica 37:157-183

Belcher C, Smooker GD (1935) Birds of the colony of Trinidad and Tobago. Part II. Ibis 1935:279-297

BirdLife International (2000) Threatened birds of the world. Lynx Edicions and Birdlife International, Barcelona and Cambridge

Brooks DM (1998) Pipile as a protein source to rural hunters and Amerindians. In: Brooks DM, Olmos F, Begazo AJ (eds) Biology and conservation of the piping guans (Aves: Cracidae). Cracid Spec Group Spec Publ 1, Houston, TX, p 42-50

Brooks DM, Strahl SD (1998) Action planning for endangered piping guans (Pipile). In: Brooks DM, Olmos F, Begazo AJ (eds) Biology and conservation of the piping guans (Aves: Cracidae). Cracid Spec Group Spec Publ 1, Houston, TX, p 52-56

Brooks DM, Strahl SD (2000) Curassows, guans and chachalacas: status survey and conservation action plan for cracids 2000-2004. International Union for the Conservation of Nature, Gland \& Cambridge

Butler P (1998) Promoting pride in the pawi. A conservation education campaign for north-east Trinidad. RARE Centre for Tropical Conservation, Philadelphia, PA, and Forestry Division, Ministry of Agriculture, Land and Marine

Editorial responsibility: Michael Reed,

Medford, Massachusetts, USA
Resources, Trinidad

Chapman FM (1894) On the birds of the island of Trinidad. Bull Am Mus Nat Hist 6:1-86

Collar NJ, Gonzaga LP, Krabbe N, Madroño Nieto A, Naranjo LG, Parker TA III, Wege DC (1992) Threatened birds of the Americas. The ICBP/IUCN Red Data Book, 3rd edn, Part 2. International Council for Bird Preservation (now BirdLife International), Cambridge

Comeau P, Guy L, Heesterman E, Hull C (1992) The Trinidad and Tobago Field Naturalists' Club trail guide. Trinidad and Tobago Field Naturalists' Club, Port of Spain

ffrench RP (1969) Two noteworthy bird records. J Trin Tob Field Nat Club 1969:29

ffrench R (1977) Some interesting bird records from Trinidad \& Tobago. J Trin Tob Field Nat Club 1977:9-10

ffrench R (1986) Additional notes on the birds of Trinidad and Tobago. J Trin Tob Field Nat Club 1985-1986:9-11

ffrench RP (1991) A guide to the birds of Trinidad \& Tobago, 2nd edn. Cornell University Press, Ithaca, NY

Hayes FE (2006) Trinidad piping-guan (Aburria pipile). In: Brooks DM (ed) Conserving cracids: the most threatened family of birds in the Americas. Misc Publ Houston Mus Sci no. 6, Houston, TX, p 32-34

Hayes FE, White G (2000) First report of the Trinidad and Tobago Rare Bird Committee. Living World. J Trin Tob Field Nat Club 1999-2000:39-45

Hayes FE, Shameerudeen CL, Sanasie B, Ramjohn CL, Lucas FB (1999) Status, ecology and behavior of the Trinidad piping-guan (Pipile pipile). Pitirre 12:64

Hayes FE, Shameerudeen CL, Sanasie B, Hayes BD, Ramjohn CL, Lucas FB (2009) Ecology and behaviour of the critically endangered Trinidad piping-guan Aburria pipile. Endang Species Res 6:223-229

Hellmayr CE (1906) On the birds of the island of Trinidad. Novit Zool 13:1-60

James C, Hislop G (1988) Status and conservation of two cracid species, the pawi or Trinidad piping-guan (Pipile pipile) and the cocrico (Ortalis ruficauda) in Trinidad and Tobago. Forestry Division, Ministry of Food Production, Forestry and Environment, Trinidad

James C, Hislop G (1997) Status and conservation of the Trinidad piping guan or pawi (Pipile pipile). In: Strahl SD, Beaujon S, Brooks DM, Begazo AJ, Sedaghatkish G, Olmos F (eds) The Cracidae: their biology and conservation. Hancock House Press, Blaine, WA, p 242-247

Quesnel V (1992) ffrench and Bacon's nature trails of Trinidad. SM Publications, Port of Spain

Reynolds RT, Scott JM, Nussbaum RA (1980) A variable circular-plot method for estimating bird numbers. Condor 82 : 309-313

Temple SA (1998) The status of Pipile pipile in Trinidad. In: Brooks DM, Olmos F, Begazo AJ (eds) Biology and conservation of the piping guans (Aves: Cracidae). Cracid Spec Group Spec Publ 1, Houston, TX, p 13

Vaurie C (1967) Systematic notes on the bird family Cracidae. No. 7, The genus Pipile. Am Mus Novit 2296:1-16

Worth CB (1973) Checklist of the birds of Bush Bush Forest. J Trin Tob Field Nat Club 1973:22-28

Submitted: September 5, 2008; Accepted: January 8, 2009

Proofs received from author(s): March 25, 2009 